\title{
Assessment of Fisheries Resources in the Babuyan Channel
}

\author{
Melanie A. Calicdan ${ }^{1}$, Ericson Gumiran ${ }^{1}$, Angel B. Encarnacion ${ }^{1, \star}$, Jovita P. Ayson ${ }^{1}$
}

${ }^{1}$ Department of Agriculture-Bureau of Fisheries and Aquatic Resources Regional Office No. 02, Regional Government Center, Tuguegarao City, Cagayan 3500 Philippines

\section{A B S T R A C T}

Babuyan Channel is one of the major fishing grounds in the country providing livelihood, income, and employment particularly to fisherfolk living in the coastal areas of the Northern Philippines thus, there is a need to assess the status of the area to determine strategies and policies to sustain its production and livelihood of the fisherfolk. The study determined the types of fishing boat and gear operating in the area, the annual fish catch estimates to include commercial and municipal production, the catch per unit effort of various gears, the seasonality of dominant species, the relative abundance and population parameters of some commercially important species to include Decapterus macrosoma, Coryphaena hippurus, and Trichiurus lepturus using data collected from 2009 to 2013, and the methods used by the National Stock Assessment Program. Most of the fishing boats and gears operating in the Babuyan Channel are under the municipal fisheries sector. However, production is higher in the commercial sector suggesting higher fishing effort and catch rate was exerted by commercial fishing boats and gears in the fishing ground. The trend of annual fish production in the fishing ground is fluctuating as reflected by the changing production in both municipal and commercial sector during the study period. The fluctuating production may be due to environmental, social, and economic factors such as increasing operation cost due to increasing fuel price, conflict, and livelihood shifting on elvers gathering in the earlier part of 2011-2012. The noted increase in 2013 was mainly due to the strict implementation of FAO 242, banning elvers gathering, and policies formulated at the local level. Drift Filter Net dominated the commercial and municipal fisheries, respectively. There were 256 species belonging to 69 families caught in the fishing ground indicating a high diversity in the area. N. tennuipes topped the production in Babuyan Channel caught by the Drift Filter Net and Pair Trawl in the mouth of Cagayan River in Aparri, Cagayan. As observed, the fishing mortality values were higher than the natural mortality, an indication that high fishing pressure is being experienced on the fishing ground.

^E-mail: angel_nacion@yahoo.com

Received: 5 May 2017

Accepted: 26 September 2017
Keywords: Babuyan Channel, Fisheries Resources, National Stock Assessment Program, Fishing Boat, Fishing Gear, Commercial Fisheries, Municipal Fisheries

\section{I N T RO D U C T I O N}

$\mathrm{T}$ he Babuyan Channel is one of the major fishing grounds in the country where multiple gear types are being used to catch multiple stocks of demersal, oceanic, and pelagic species thus, providing livelihood, income, and employment to fisherfolk living in the coastal areas. It contributes $64 \%$ and $48 \%$ of the total fisheries production of the province of Cagayan and Cagayan Valley Region in 2013 (DA-BFAR 2 2013), respectively. As such, the need to assess the status of the fishing ground is important to determine strategies and policies to sustain its production thus, sustaining also the livelihood of the local fisherfolk.

The status of overfishing in the area can be determined when the catch and catch rate are observed to be declining; increasing effort, mortalities, and exploitation rates are noted; and changes or shift in species composition, levelling of marine landings, and concentration of fishing effort within a small area are being observed (Armada 2004).

Thus, this study was undertaken to provide additional documentation and information on the status of fishery resources vital for policy formulation, management, and conservation of the aquatic resources in the Babuyan Channel.

Specifically, it determined the types of fishing boat and gear operating in the area, annual fish catch estimates to include commercial and municipal production, catch per unit effort of various gears, seasonality of dominant species, relative abundance and population parameters of some commercially important species. The data used in this study were mainly from the municipal and commercial fisheries data collected from the established National Stock Assessment Program (NSAP) landing centers covering Babuyan Channel. The study only covered a five-year period, from 2009-2013. 


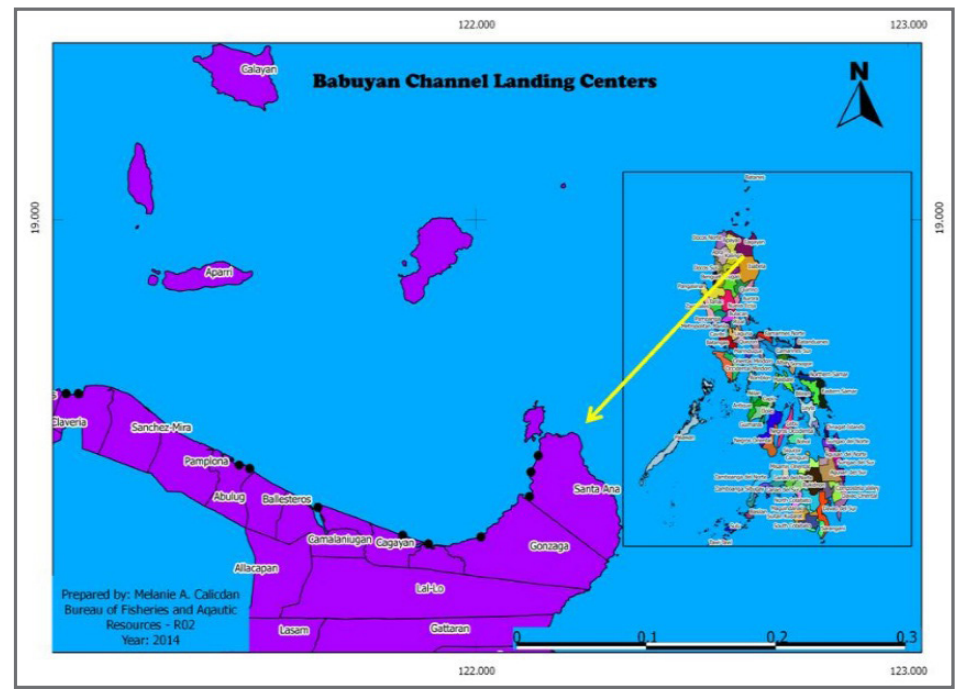

Figure 1. Map of Northern Cagayan indicating the municipalities covered by the study.

\section{ME T H O D O L O G Y}

\section{Study Area}

The study was carried out in 12 landing sites (Centro and Palawig in Sta. Ana, Batangan and Minanga in Gonzaga, Minanga and Centro in Buguey, Centro and Bagu in Abulug, Centro and Punta in Aparri, and Taggat and Minanga in Claveria) as seen in Figure 1. It lies approximately between latitude $18^{\circ} 16^{\prime} 00^{\prime \prime}$ and $11^{\circ} 35^{\prime} 00^{\prime \prime}$ North and longitude $121^{\circ} 02^{\prime} 00^{\prime \prime}$ and $121^{\circ}$ $14^{\prime} 30^{\prime \prime}$ East. It has a coastline length of around $154 \mathrm{~km}$ connecting eleven (11) coastal municipalities of Cagayan from Sta. Praxedes on the west to Sta. Ana on the east. It has a total area of approximately 477,550 hectares. The Northern part of the channel extends to the islands of Fuga, Camiguin, Dalupiri, Calayan, and Babuyan Group of Islands converging with the Pacific Ocean on the East and the West Philippine Sea on the West. The center of the channel, within the territorial waters of the Municipality of Aparri, is estuarine in nature where the largest and longest river in the entire archipelago, the Cagayan River lies.

\section{Data Collection}

The data were collected by trained enumerators assigned to the 12 landing sites. Data collection and sampling techniques used were the standard NSAP method. The data were collected every other two days regardless of Saturdays, Sundays, and Holidays. The information gathered includes the total number of fishing boats landed per sampling day, type of gear, total catch and effort per fishing operation, number of fishing days, number of hauls, length measurements, and species composition. The sampling of the catch was done by taking fish samples randomly from the fish holds/tubs/ styrofoams, sorted by species and weighed each species component to determine the total weight of each species from the catch. All these information were recorded on the prepared NSAP forms and submitted for collation, encoding, and processing at the BFAR Regional Office 02.

\section{Data Processing and Analysis}

$w$ Fishing boats and gears for both municipal and commercial fisheries were inventoried to come up reliable fish catch estimation in the fishing ground. To come up with the average tonnage of all municipal and commercial boats, total tonnage was divided by the number of boats landed. Separate computations on the average gross tonnage were made for commercial and municipal fishing boats. The latest data for the commercial and municipal boats was based on the C.Y 2013 boat and gear inventory.

Production Estimate. Raised catch data per month was obtained following the procedure of Aragon et. al. (2008). To derive the raised catch per month, the following equation was used:

$$
\begin{gathered}
\text { Ave. } \text { catch } / \text { boat }=\text { Monitored monthly production / } \\
\text { total boat landings }
\end{gathered}
$$

The result was then multiplied by $50 \%$ of the total number of fishing boats during lean season and $60 \%$ of the total number of fishing boats during peak season, and then multiplied by the total number of fishing days for the month to come up with the estimated catch for the month. The number of fishing days for the month during peak season (March to May) is estimated at 22 fishing days, and during lean season (June to February) at 12 fishing days (Aragon et al. 2008).

Catch Per Unit Effort (CPUE). Monthly CPUE per gear was computed and standardized as kilogram/ boat. The annual CPUE was obtained by summing all the total monthly harvest (in kilograms) divided by the total number of fishing boats landed for the whole year.

Dominant Species. Fish species caught by 
Table. 1. Inventory of municipal and commercial fishing boats in Babuyan Channel, 2013.

\begin{tabular}{|c|c|c|c|c|c|c|c|c|c|c|c|}
\hline \multirow{3}{*}{ Municipalities } & \multicolumn{4}{|c|}{ Motorized } & \multirow{3}{*}{$\begin{array}{l}\text { Sub- } \\
\text { total }\end{array}$} & \multirow{2}{*}{\multicolumn{2}{|c|}{ Non-motorized }} & \multirow{3}{*}{$\begin{array}{l}\text { Sub- } \\
\text { total }\end{array}$} & \multirow{2}{*}{\multicolumn{2}{|c|}{ TOTAL }} & \multirow{3}{*}{$\begin{array}{c}\text { GRAND } \\
\text { TOTAL }\end{array}$} \\
\hline & \multicolumn{2}{|c|}{ Inboard } & \multicolumn{2}{|c|}{ Outboard } & & & & & & & \\
\hline & Comm'l. & Mun'l. & Comm'l. & Mun'l. & & Comm'l. & Mun'l. & & Comm'l. & Mun'l. & \\
\hline & & & & & & & & & & & \\
\hline Calayan & & 104 & & & 104 & & 197 & 197 & & 301 & 301 \\
\hline Aparri & 54 & 467 & 82 & 10 & 613 & & 101 & 101 & 136 & 578 & 714 \\
\hline Buguey & 11 & 111 & & & 122 & & 77 & 77 & 11 & 188 & 199 \\
\hline Sta. Ana & & 306 & & & 306 & 16 & & 16 & 16 & 306 & 322 \\
\hline Gonzaga & 22 & 184 & & & 206 & 19 & 30 & 49 & 41 & 214 & 255 \\
\hline Pamplona & & 24 & 45 & 55 & 124 & & 123 & 123 & 45 & 202 & 247 \\
\hline Abulug & & & 30 & 66 & 96 & & 28 & 28 & 30 & 94 & 124 \\
\hline Ballesteros & 5 & 60 & 7 & 5 & 77 & & 20 & 20 & 12 & 85 & 97 \\
\hline Sanchez Mira & & 122 & & 4 & 126 & 1 & 29 & 30 & 1 & 155 & 156 \\
\hline Claveria & & 152 & & & 152 & & 66 & 66 & & 218 & 218 \\
\hline Sta. Praxedes & & 32 & & & 32 & & 13 & 13 & & 45 & 45 \\
\hline TOTAL & 92 & 1530 & 164 & 140 & 1958 & 36 & 671 & 720 & 292 & 2341 & 2678 \\
\hline$\%$ & $3 \%$ & $57 \%$ & $6 \%$ & $5 \%$ & $73 \%$ & $1 \%$ & $25 \%$ & $27 \%$ & $11 \%$ & $87 \%$ & $100 \%$ \\
\hline
\end{tabular}

commercial and municipal fishing boats were ranked from highest to lowest, which is summing all the total catch of each species from the pooled gear during the study period to determine the five (5) top commercially important fish species in the area.

Seasonality of Commercially Important Species. Monthly catch (in kilograms) was used to determine the relative abundance and seasonality of some commercially important species. The data used in the estimation of the seasonality and relative abundance was the monitored raw production values.

Population Parameters. Population parameters were obtained using the FAO-ICLARM Stock Assessment Tools (FISAT) software (Gayanilo et.al. 1996).

Mortality and Exploitation Rates. The length samples of the species subjected to the analysis of population parameters from different gears were pooled to simulate a steady state population. Total mortality coefficient (Z) was estimated by length converted catch curve procedure of ELEFAN II. Natural mortality was calculated by Pauly's empirical equation.

$$
\mathrm{Z}=\mathrm{M}+\mathrm{F}
$$

where $\mathrm{Z}$ is the instantaneous total mortality, $\mathrm{M}$ is the instantaneous natural mortality due to predation, aging, and other environmental causes, and $\mathrm{F}$ is the instantaneous fishing mortality caused by fishing. The total mortality was obtained from the slope (b) of the descending limb of the catch curved with the sign changed. Instantaneous natural mortality (M) was estimated using Pauly's (1984) empirical formula:

$$
\log M=0.654 \log k-0.28 \log L_{\infty}+0.463 \log T
$$

where $\mathrm{L}_{\infty}$ and $\mathrm{K}$ are the Von Bertalanffy Growth Function (VBGF) growth parameters and $\mathrm{T}$ was the annual mean habitat temperature $\left(28^{\circ} \mathrm{C}\right)$ taken as an annual average temperature of the area. The asymptotic length and the growth constant $(\mathrm{K})$ value of the species were already provided by the software. However, the value obtained was compared to the value listed on the website of FishBase to have a confident $\mathrm{K}$ scan value for particular species. The ratios of the coefficients of mortality and growth $(\mathrm{Z} / \mathrm{K})$ were estimated using the Powell-Wetherall plot (Powell 1979; Wetherall 1986; Gayanilo and Pauly 1997). Natural mortality (M) was estimated using the M-empirical equation of Pauly (1984). Values obtained for mortality were used in the computation of exploitation rate.

$$
\mathrm{E}=\mathrm{F} /(\mathrm{F}+\mathrm{M})
$$

where $\mathrm{E}$ is the exploitation rate. Using the equation on growth parameters and mortalities, prediction of recruitment patterns and virtual population analysis were estimated using the routines found in FISAT programs (Gayanilo and Pauly 1997).

Recruitment Patterns. Recruitment is the process by which young fish enter the exploited area and become liable to contact with fishing gear. Relative yield per recruit and biomass per recruit models of Beverton and Holt's (1957) as modified by Pauly and Soriano (1996) were used for the prediction of yield and standing biomass. The relative yield per recruit $(\mathrm{Y} / \mathrm{R})$ and relative biomass per recruit $(B / R)$ were determined by Ogive selection approach, while the yield per recruit model is incorporated into the recruitment routine in FiSAT (Pauly 1983; Gayanilo et al. 1995; Gayanilo and Pauly 1997).

\section{R E S U L T S}

\section{Fishing Boats and Gear Inventory}

Table 1 shows the distribution of fishing boats operating in the Babuyan Channel classified into commercial and municipal boats. A total of 2,678 fishing boats (motorized and non-motorized) were noted to be 
Table 2. Distribution of municipal and commercial fishing gears in Babuyan Channel, 2013.

\begin{tabular}{|c|c|c|c|c|c|c|c|c|c|c|c|c|c|c|}
\hline \multirow[b]{2}{*}{ Type of Gear } & \multirow[b]{2}{*}{ Classification } & \multicolumn{11}{|c|}{ Municipality } & \multirow[b]{2}{*}{ TOTAL } & \multirow{2}{*}{$\stackrel{\%}{\text { Distribution }}$} \\
\hline & & ta. Praxede & Claveria & panchez Mir & Pamplona & Abulug & Ballesteros & Aparri & Buguey & Gonzaga & Sta. Ana & Calayan & & \\
\hline Purse Seine & Comm'l. & & & & & & & & & & & & 0 & $0.00 \%$ \\
\hline Round Haul Sein & Comm'l. & & & & & & & & & 5 & 10 & & 15 & $0.25 \%$ \\
\hline \begin{tabular}{|l|} 
Drift Filter Net \\
\end{tabular} & Comm'l. & & & & & 17 & & 27 & & & & & 44 & $0.72 \%$ \\
\hline Beach Seine & Comm'l. & & & 1 & 2 & & 1 & & & 3 & & & 7 & $0.12 \%$ \\
\hline Danish Seine & Comm'l. & & & & & & & & 11 & & & & 11 & $0.18 \%$ \\
\hline Modified Drift Filt & Comm'l. & & & & & 30 & & 83 & & & & & 113 & $1.86 \%$ \\
\hline Ring Net & Comm'l. & & & & 45 & 21 & 1 & & & 6 & 6 & & 79 & $1.30 \%$ \\
\hline \multicolumn{2}{|c|}{ Subtotal } & & & 1 & 47 & $\underline{68}$ & $\underline{2}$ & $\underline{110}$ & 11 & $\underline{14}$ & $\underline{16}$ & & 269 & $4.43 \%$ \\
\hline Gillnet & Mun'l. & 32 & 104 & 1230 & 307 & 23 & 31 & 269 & 114 & 146 & 270 & 179 & 2705 & $44.53 \%$ \\
\hline Multiple Handline & Mun'l. & & 179 & & & & & & & & & & 179 & $2.95 \%$ \\
\hline \begin{tabular}{|l|} 
Handline \\
\end{tabular} & Mun'l. & & & & & & 73 & 45 & & & & & 118 & $1.94 \%$ \\
\hline Troll Line & Mun'l. & & 101 & & & & & 81 & & & & 67 & 249 & $4.10 \%$ \\
\hline Simple Handline & Mun'l. & & & & & & 17 & 71 & & & & & 88 & $1.45 \%$ \\
\hline \begin{tabular}{|l|} 
Longline \\
\end{tabular} & Mun'l. & & 13 & & 45 & & 39 & 128 & & & 125 & 60 & 410 & $6.75 \%$ \\
\hline Baguyboy & Mun'l. & & & & & & 25 & & & & & & 25 & $0.41 \%$ \\
\hline \begin{tabular}{|l|} 
Fyke Net \\
\end{tabular} & Mun'l. & & & & 18 & 20 & 5 & 270 & 62 & 30 & & & 405 & $6.67 \%$ \\
\hline Fish Net & Mun'l. & & & & 45 & & 52 & & & & & & 97 & $1.60 \%$ \\
\hline Trawl & Mun'l. & & & & & 10 & & 70 & 72 & 8 & & & 160 & $2.63 \%$ \\
\hline Traik & Mun'l. & & & & & & & & 50 & & & & 50 & $0.82 \%$ \\
\hline Attag & Mun'l. & & & & & 120 & & & & & & & 120 & $1.98 \%$ \\
\hline Hook and Line & Mun'l. & 16 & & 615 & 32 & & 1 & 66 & & 35 & 12 & 124 & 901 & $14.83 \%$ \\
\hline Jigger & Mun'l. & & & & & & & & & & & & 0 & $0.00 \%$ \\
\hline Hawk & Mun'l. & & & & & & 2 & & & & & & 2 & $0.03 \%$ \\
\hline Crab Lift Net & Mun'l. & & & & & & & & & & & & 0 & $0.00 \%$ \\
\hline Cast Net & Mun'l. & 2 & & & & 2 & 69 & 3 & & & & & 76 & $1.25 \%$ \\
\hline Spear Gun & Mun'l. & 39 & & & & & & & & & 14 & 9 & 62 & $1.02 \%$ \\
\hline Beach Seine & Mun'l. & & 39 & 28 & 1 & & & & 1 & 8 & & & 77 & $1.27 \%$ \\
\hline Kurarawi & Mun'l. & 24 & & & & & & & & & & & 24 & $0.40 \%$ \\
\hline Sayot & Mun'l. & & & & & & & 2 & & & & & 2 & $0.03 \%$ \\
\hline Crab Pot & Mun'l. & & & & & & & & 2 & & & & 2 & $0.03 \%$ \\
\hline Scoop Net & Mun'l. & & & & & & & & & & 21 & & 21 & $0.35 \%$ \\
\hline Crab Trap & Mun'l. & & & & & 32 & & & & & & & 32 & $0.53 \%$ \\
\hline \multicolumn{2}{|c|}{ Subtotal } & 113 & 436 & 1873 & $\underline{448}$ & $\underline{207}$ & $\underline{314}$ & $\underline{1005}$ & $\underline{301}$ & $\underline{227}$ & $\underline{442}$ & $\underline{439}$ & $\underline{5805}$ & $95.57 \%$ \\
\hline \multicolumn{2}{|c|}{ Grand Total } & 113 & 436 & 1874 & 495 & 275 & 316 & $\overline{1115}$ & 312 & 241 & 458 & 439 & 6074 & $100.00 \%$ \\
\hline
\end{tabular}

operating in the fishing ground in 2013 . Only $11 \%$ of the fishing boats were under commercial while a bulk of it is classified as municipal.

Meanwhile, there were 6,074 units of fishing gears being used in the 11 coastal municipalities along the Babuyan Channel (Table 2). Out of the total number of fishing gears, only $6 \%$ of these were commercial while rest were municipal. At least 30 kinds of fishing gears are being used in the fishing ground. Gillnet has the highest percentage share composed of bottom set gill net, surface gill net, and tuna gill net. The gear was noted to be widely used by marginal fisherfolk in the area.

\section{Annual Fish Production Trend}

The annual fish harvest for commercial fisheries slightly decreased from 2009 to 2012 and abruptly increased in 2013 (Figure 2). Likewise, the annual harvest for municipal fisheries fluctuated from 2009 to 2013 . The estimated production slightly increased in 2009-2010 but decreased in 2010-2012 and again increased in 2013.

Top five (5) commercial fishing gears operating in the Babuyan Channel during the study period in decreasing percentage share were Drift Filter Net, Danish Seine, Pair Trawl, Round Hail Seine, and Ring Net as shown in Figure 3. Highest average CPUE was observed in Drift Filter Net followed by Danish Seine, Purse Seine, Round Haul Seine, Pair Trawl and the rest of the

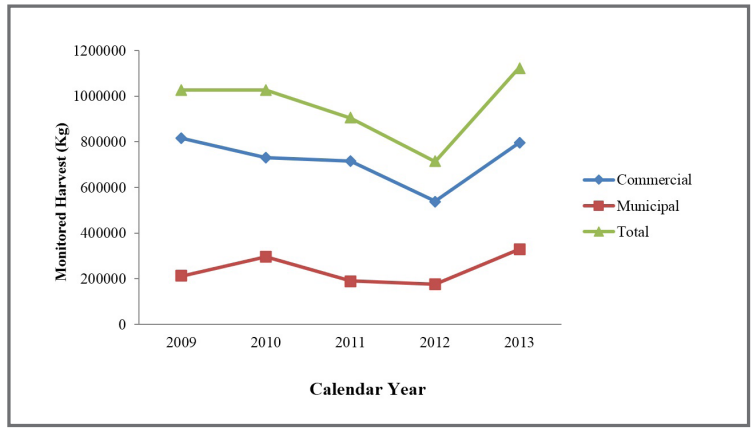

Figure 2. Annual fish harvest in Babuyan Channel (2009-2013).

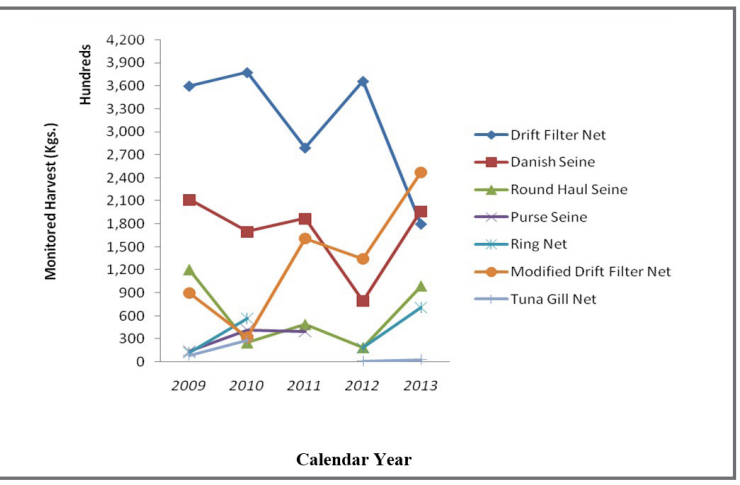

Figure 3. Commercial fish production trend by gear in Babuyan Channel (2009-2013). 


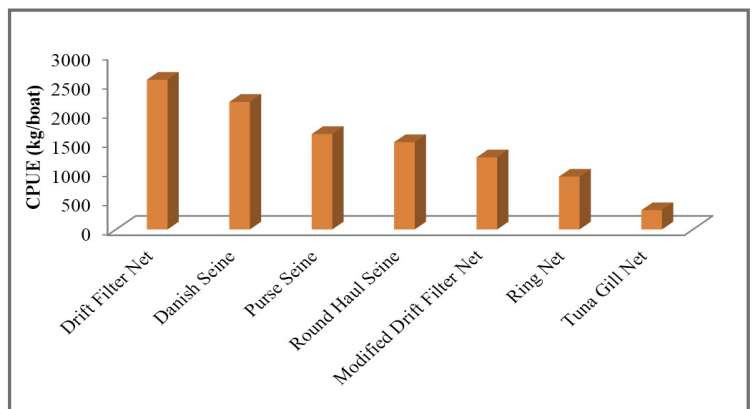

Figure 4. Average catch per unit effort (CPUE) of commercial fishing gears operating in Babuyan Channel (2009-2013).

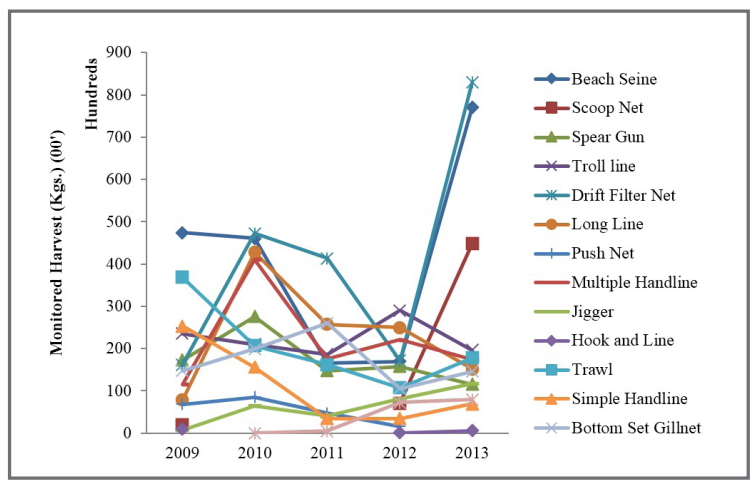

Figure 5. Municipal fish production trend by gear in Babuyan Channel (2009-2013).

commercial gears share the remaining catch (Figure 4).

Figure 5 shows the most common gears used in municipal waters. Increase harvest was observed in Drift Gill Net followed by Beach Seine, Longline, Troll Line, Multiple Hand Line, Trawl, Spear Gun, Bottom Set Gill Net, Simple Hand Line, Scoop Net, Jigger, Push Net, Fyke Net, and Hook and Line. Municipal fishing gear with the highest CPUE was Beach Seine followed by Scoop Net, Spear Gun, and the rest of the fishing gears (Figure 6).

\section{Catch Composition}

A total of 256 species belonging to 69 families were identified from the recorded harvest during the study period (Table 3). Vertebrate species comprised $96 \%$ of the total landed catch wherein $72 \%$ were pelagic and $24 \%$ were demersal species. Invertebrate species comprised 3\% and 1\% for the Elasmobranch species.

Pelagics were represented by 11 fish families, and 2 families of shrimps. Demersal species were represented by 44 families of fish, 2 families of shells, 2 families of squids, 2 families of crabs, 1 family of lobster, 2 families of rays, 2 families of sharks, and 1 family of guitarfishes. The most abundant and top producer groups in vertebrates family were: Family Scombridae (mackerels, tunas, bonitos), followed by Carangidae (jacks and pampanos), Engraulidae (anchovies), Coryphaenidae (dolphinfishes), and Clupeidae (herrings, shads, sardines, and menhandens). Family Palaemonidae (spider shrimp) dominated the catch of all invertebrates followed by

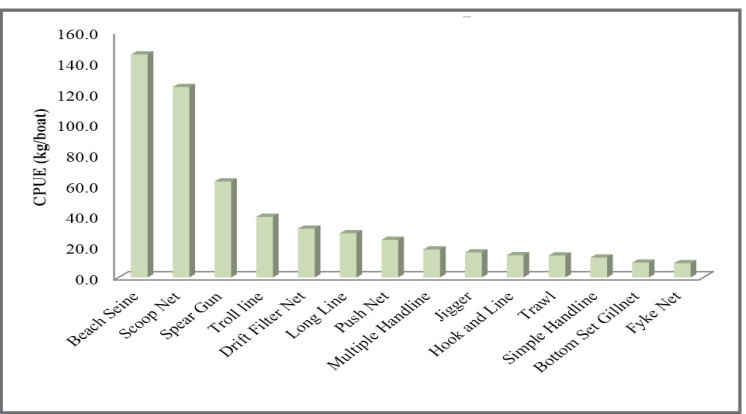

Figure 6. Average catch per unit effort (CPUE) of municipal fishing gears operating Babuyan Channel (2009-2013).

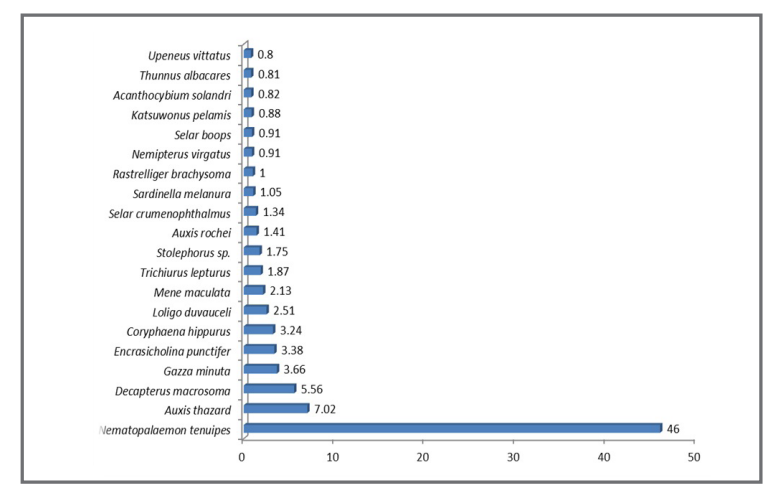

Figure 7. Ranking of the twenty dominant fish species in Babuyan Channel (2009-2013).

Family Loliginidae (squids), and Family Dasyatidae (rays) for the elasmobranch fishes.

Nematopalaemon tenuipes ranked with a percentage abundance of $46 \%$ followed by Auxis thazard, Decapterus macrosoma, Gazza minuta, Encrasicholina punctifer, and other species (Figure 7).

\section{Seasonality of Dominant Species}

Figure 8 shows the seasonal distribution of the major fish species monitored in Babuyan Channel. As reported earlier, $N$. tenuipes locally known as "aramang," the top commercially important species observed in the fishing ground, has its peak starting August to January. A. thazard locally known as "tangi," the second most dominant species, was present all year round. The peak season occurs during the months of May to July and December to January. D. macrosoma, locally known as "baraniti," the third most dominant species observed during the study period, has fluctuating monthly production with paks in April to June and lean season in September. Gazza minuta, locally known as "sapsap/ lalakasen," the fourth commercially important species caught in the fishing ground, has its peak season in March to June and August and lean season in October to December. E. punctifer, locally known as "munamun," is the fifth commercially important species in the Babuyan Channel were observed to be abundant during summer months (March to April) except for N. tenuipes which was observed to be present throughout the year, but it is 
Table 3. Catch composition in Babuyan Channel (2009-2013).

\begin{tabular}{|c|c|c|c|c|}
\hline Habitat & Family & Common Name & $\begin{array}{c}\text { Monitored } \\
\text { Harvest }\end{array}$ & Abundance \\
\hline Vertebrates & & & (kgs) & $(\%)$ \\
\hline \multirow{11}{*}{ Pelagics } & Chanidae & milkfish & 941 & 0.037 \\
\hline & Chinocentridae & wolf herrings & 80 & 0.003 \\
\hline & Clupeidae & herrings, shads, sardines, menhandens & 125171 & 4.982 \\
\hline & Coryphaenidae & dolphinfishes & 155000 & 6.170 \\
\hline & Engraulidae & anchovies & 307020 & 12.221 \\
\hline & Exocoetidae & flying fishes & 19680 & 0.783 \\
\hline & Hemiramphidae & halfbeaks & 6230 & 0.248 \\
\hline & Istiophoridae & billfishes, marlins & 12440 & 0.495 \\
\hline & Mugillidae & mullets & 460 & 0.018 \\
\hline & Pristigasteridae & pristigasterids & 680 & 0.027 \\
\hline & Scombridae & mackerels, tunas, bonitos & 574403 & 22.864 \\
\hline Sub-total & & & 1202105 & 47.850 \\
\hline \multirow{44}{*}{ Demersal } & Acanthuridae & surgeonfishes, unicornfishes, tangs & 470 & 0.019 \\
\hline & Anguilidae & anguilids & 1492 & 0.059 \\
\hline & Belonidae & needlefishes & 1820 & 0.072 \\
\hline & Bothidae & large-eye flounders & 200 & 0.008 \\
\hline & Caesionidae & fusiliers & 5982 & 0.238 \\
\hline & Carangidae & jacks and pampanos & 427691 & 17.024 \\
\hline & Centropomidae & ray finned fishes, snooks & 890 & 0.035 \\
\hline & Cynoglossidae & tonguefishes & 1520 & 0.061 \\
\hline & Cyprinidae & carps, minnows & 1470 & 0.059 \\
\hline & Drepaneidae & sicklefishes & 20 & 0.001 \\
\hline & Elopidae & tenpounders & 71 & 0.003 \\
\hline & Ephippidae & spadefishes & 0.2 & 0.000 \\
\hline & Gerridae & mojarras & 90 & 0.004 \\
\hline & Gobiidae & gobies & 22220 & 0.884 \\
\hline & Haemulidae & grunts & 1550 & 0.062 \\
\hline & Holocentridae & squirrelfish & 410 & 0.016 \\
\hline & Kurtidae & forehead brooders, nursery fishes & 12 & 0.000 \\
\hline & Kyphosidae & sea chubs & 31 & 0.001 \\
\hline & Lactariidae & false travelly & 70 & 0.003 \\
\hline & Leiognathidae & slipmouths, ponyfishes, slimys & 213610 & 8.503 \\
\hline & Lethrinidae & emperors & 13422 & 0.534 \\
\hline & Lobotidae & trippletails & 50 & 0.002 \\
\hline & Lutjanidae & snappers & 8537 & 0.340 \\
\hline & Menidae & moonfish & 83830 & 3.337 \\
\hline & Monocanthidae & leatherjacks & 4 & 0.000 \\
\hline & Mullidae & goatfishes & 42878 & 1.707 \\
\hline & Muraenidae & moray eels & 10040 & 0.400 \\
\hline & Nemipteridae & threadfin and whiptail breams & 46396 & 1.847 \\
\hline & Pagasiidae & shark catfish & 380 & 0.015 \\
\hline & Paralichthyidae & flounders & 890 & 0.035 \\
\hline & Priacanthidae & bigeyes, catalufas & 650 & 0.026 \\
\hline & Platycephalidae & flatheads & 110 & 0.004 \\
\hline & Plotosidae & eel tail catfish & 3 & 0.000 \\
\hline & Psettodidae & spiny turbots & 50 & 0.002 \\
\hline & Scaridae & parrotfishes & 39330 & 1.566 \\
\hline & Sciaenidae & drums, soldier croakers & 27754 & 1.105 \\
\hline & Serranidae & sea bass & 3923 & 0.156 \\
\hline & Siganidae & siganids & 7180 & 0.286 \\
\hline & Sillaginidae & whitings, sand borers, sand-smelts & 110 & 0.004 \\
\hline & Soleidae & sole fishes & 530 & 0.021 \\
\hline & Sparidae & breams & 1160 & 0.046 \\
\hline & Synodontidae & lizardfishes & 10972 & 0.437 \\
\hline & Teraponidae & teraponids & 80 & 0.003 \\
\hline & Trichiuridae & hairtails & 160862 & 6.403 \\
\hline Sub-total & & & 1138760.2 & 45.329 \\
\hline \multicolumn{5}{|l|}{ Invertebrates } \\
\hline Pelagics & Palaemonidae & spider shrimp & 2210240 & 87.979 \\
\hline
\end{tabular}




\begin{tabular}{|c|l|l|c|c|}
\hline Habitat & \multicolumn{1}{|c|}{ Family } & \multicolumn{1}{|c|}{ Common Name } & $\begin{array}{c}\text { Monitored } \\
\text { Harvest }\end{array}$ & Abundance \\
\hline & Penaeidae & shrimps & 39700 & 1.580 \\
\hline Demersal & Cyrenidae & Batissa & 4 & 0.0002 \\
\hline & Calappidae & bivalves & 16 & 0.0006 \\
\hline & Loliginidae & squids & 141410 & 5.6289 \\
\hline & Ommastrephidae & squids & 10 & 0.0004 \\
\hline & Palinuridae & lobsters & 33 & 0.0013 \\
\hline & Portunidae & crabs & 10673 & 0.4248 \\
\hline & Scyllaridae & crabs & 190 & 0.0076 \\
\hline Sub-total & & & $\mathbf{1 5 2 3 3 6}$ & $\mathbf{6 . 0 6 4}$ \\
\hline Elasmobranchs & Dasyatidae & rays & 10190 & 0.406 \\
\hline & Myliobathidae & eagles and manta rays & 520 & 0.021 \\
\hline & Sphyrnidae & sharks & 183 & 0.007 \\
\hline & Carharhinidae & requim sharks & 8130 & 0.324 \\
\hline Sub-total & Rhyncobatidae & guitarfishes & $\underline{\mathbf{1 9 0 2 3}}$ & 0.002 \\
\hline Grand Total & & & $\underline{\mathbf{2 5 1 2 2 2 4 . 2}}$ & $\underline{\mathbf{1 0 0 . 0 0 0}}$ \\
\hline
\end{tabular}

Table 4. Growth parameter estimates of selected commercially important species in Babuyan Channel (2009-2013). *Source: Aragon et.al. $2008{ }^{*}$ Values obtained from Fish Base (Manila Bay result)

\begin{tabular}{|c|c|c|c|c|}
\hline Species & Year & $\operatorname{Lmax}(\mathrm{cm})$ & $\operatorname{Loo}(\mathrm{cm})$ & $\mathrm{K}(\mathrm{yr}-1)$ \\
\hline & 2009 & 22.5 & 23.63 & 0.56 \\
\hline Decapterus macrosoma & 2010 & 26 & 28 & 0.62 \\
\hline (TL) & 2011 & 22 & 24.5 & 0.55 \\
\hline & 2012 & 25 & 27.3 & 0.92 \\
\hline & 2013 & 29 & 31.5 & 0.65 \\
\hline Values from Fish base & & $28^{*}$ & $31.5^{\star \star}$ & $0.65-0.71^{\star *}$ \\
\hline & 2009 & 186 & 195.3 & 0.52 \\
\hline & 2010 & 180 & 189 & 0.42 \\
\hline Coryphaena hippurus & 2011 & \multicolumn{3}{|c|}{ Length frequency data is insufficient } \\
\hline$(\mathrm{FL})$ & 2012 & 134 & 140.7 & 0.5 \\
\hline & 2013 & 215 & 225.75 & 0.6 \\
\hline Values from literature & & $148.01^{\star}$ & $174^{\star}$ & $0.48^{\star}$ \\
\hline & 2009 & \multicolumn{3}{|c|}{ No modal progression } \\
\hline & 2010 & 145 & 152.25 & 0.4 \\
\hline Trichiurus lepturus & 2011 & \multicolumn{3}{|c|}{ No modal progression } \\
\hline (TL) & 2012 & 107.5 & 112.88 & 0.510 \\
\hline & 2013 & 160 & 168 & 0.25 \\
\hline Values from Fish base & & $110^{*}$ & $64.5-78^{\star \star}$ & $0.41-0.7^{\star}$ \\
\hline
\end{tabular}

more abundant during colder months and when frequent precipitation occurs.

\section{Population Parameters of Some Commercially Important Species}

Growth parameter estimates for some commercially important species (e.g. Decapterus macrosoma, Coryphaena hippurus, and Trichiurus lepturus) were presented in Table 4. The $\mathrm{L}_{\max }$ value obtained for D. macrosoma varies from 2009 to 2013. The highest Lmax and $\mathrm{L}_{\infty}$ value obtained was $29 \mathrm{~cm}$ and $31.5 \mathrm{~cm}$, respectively. Lmax and $\mathrm{L}_{\infty}$ from FishBase were $28 \mathrm{~cm}$ and $31.5 \mathrm{~cm}$, respectively. $\mathrm{K}$ values obtained for the species in this study range from 0.56 to $0.92 \mathrm{~cm} /$ year $^{-1}$ while 0.65 to $0.71 \mathrm{~cm} /$ year- 1 from FishBase.

For C. hippurus, the $\mathrm{L}_{\infty}$ decreased from 195.3 $\mathrm{cm}$ in 2009 to 140.7 in 2012 except for 2013 when the highest value obtained $225.75 \mathrm{~cm}$. The Lmax value and $\mathrm{L}_{\infty}$ from Fish Base were $148.01 \mathrm{~cm}$ and $174 \mathrm{~cm}$, respectively. $\mathrm{K}$ values obtained for the species in this study range from 0.42 to $0.6 \mathrm{~cm} /$ year $^{-1}$ while from Fish Base was $0.48 \mathrm{~cm} /$ year-1.

For T. lepturus, $\mathrm{L}_{\max }$ and $\mathrm{L}_{\infty}$ varied from CY 2010 to CY 2013 except for the year CY 2009 and CY 2011 in which no modal progression was obtained. The highest value obtained for Lmax was $110 \mathrm{~cm}$ from Fish Base. K values obtained for the species from this study range from 0.25 to $0.5 \mathrm{~cm} /$ year $^{-1}$ whereas 0.41 to $0.7 \mathrm{~cm} /$ year $^{-1}$ from Fish Base.

Table 5 shows the mortality of these species during the study period. The total mortality $(\mathrm{Z})$ of $D$. macrosoma varies from one year to another during the study period. The maximum length observed during the study period was $30 \mathrm{~cm}$ and $8 \mathrm{~cm}$ for the shortest length. As observed, the fishing mortality (F) values for $D$. macrosoma were higher than the natural mortality $(\mathrm{M})$ values which obtained a total mortality $(\mathrm{Z})$ of 3.14 to 
Table 5. Mortality parameter estimates of selected commercially important species in Babuyan Channel (2009-2013)

\begin{tabular}{|c|c|c|c|c|c|c|}
\hline Species & $\begin{array}{c}\text { Mortality Parameters } \\
\text { (yr-1) }\end{array}$ & $\mathbf{2 0 0 9}$ & $\mathbf{2 0 1 0}$ & $\mathbf{2 0 1 1}$ & $\mathbf{2 0 1 2}$ & $\mathbf{2 0 1 3}$ \\
\hline Decapterus macrosoma & $\mathrm{M}$ & 1.31 & 1.33 & 1.28 & 1.74 & 1.33 \\
\hline & $\mathrm{tF}$ & 3.29 & 1.81 & 3.09 & 3.07 & 1.99 \\
\hline & $\mathrm{Z}$ & 4.6 & 3.14 & 4.37 & 4.81 & 3.32 \\
\hline Coryphaena hippurus & $\mathrm{M}$ & 0.69 & 0.61 & - & 0.74 & 0.73 \\
\hline & $\mathrm{F}$ & 5.19 & 4.17 & - & 0.93 & 6.79 \\
\hline & $\mathrm{Z}$ & 5.88 & 4.78 & - & 1.67 & 0.9 \\
\hline Trichiurus lepturus & $\mathrm{M}$ & - & 0.62 & - & 0.79 & 0.45 \\
\hline & $\mathrm{F}$ & - & 1.81 & - & 3.23 & 4.22 \\
\hline & $\mathrm{Z}$ & - & 2.43 & - & 4.02 & 4.67 \\
\hline
\end{tabular}

Table 6. Recruitment pattern estimates of selected commercially important species in Babuyan Channel (2009-2013).

\begin{tabular}{|c|c|c|c|}
\hline Species & $\begin{array}{c}\text { Pulses per } \\
\text { year }\end{array}$ & Major pulse & Minor pulse \\
\hline Decapterus macrosoma & 2 & May-April & September-July \\
\hline Coryphaena hippurus & 2 & March-May & August-September \\
\hline Trichiurus lepturus & 2 & April-June & October \\
\hline
\end{tabular}

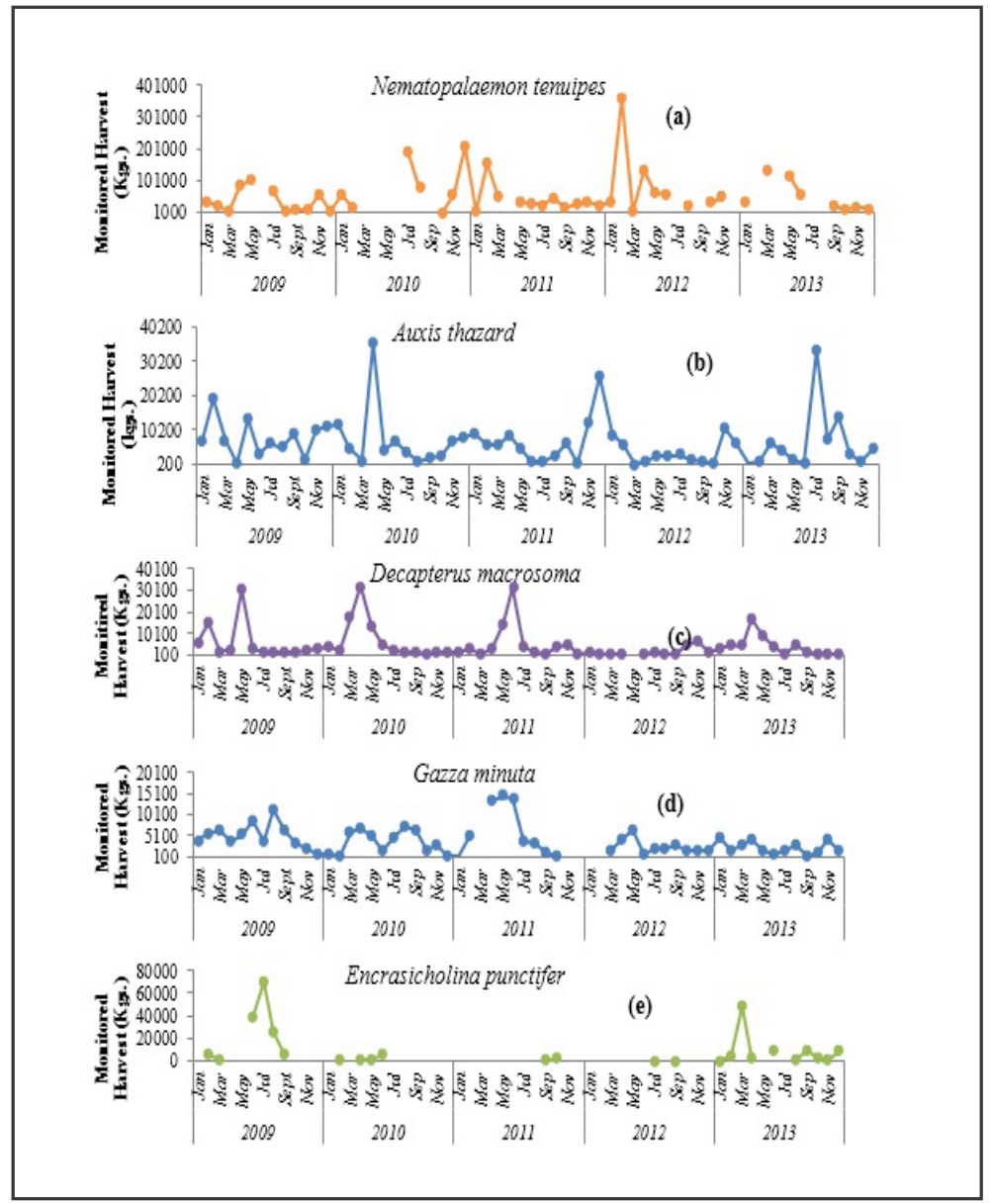

Figure 8. Seasonality trend of major commercially important species a) N. tenuipes, b) A. thazard c) D. macrosoma, d) G. minuta, e) E. punctifer based on monthly catch (kgs.) (2009-2013). 


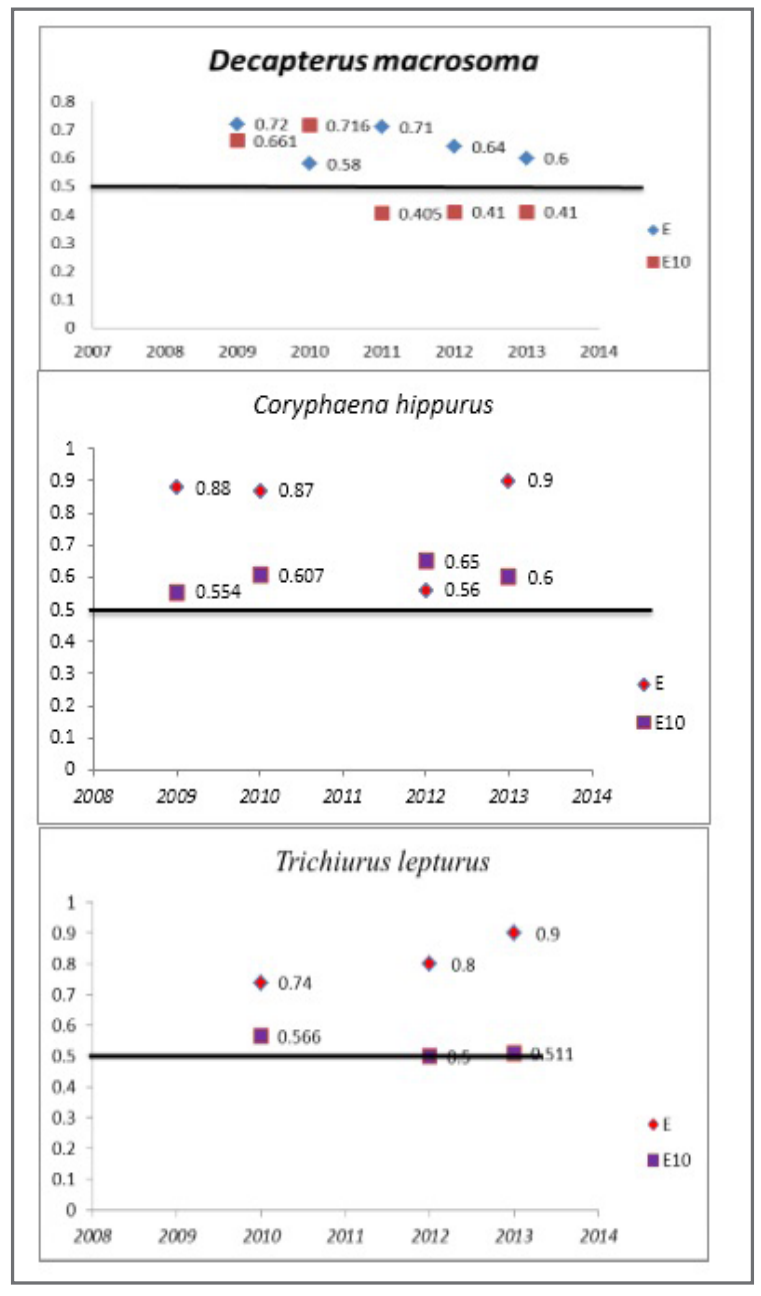

Figure 9. Estimated exploitation rate of Decapterus macrosoma, Coryphaena hippurus and Trichiurus lepturus in Babuyan Channel (2009- 2013).

$4.81 /$ year $^{-1}$.

On the other hand, the total mortality of $C$. hippurus was noted to be decreasing from 2009 to 2013. The maximum length observed during the study period was $180 \mathrm{~cm}$ and the minimum length was $22.5 \mathrm{~cm}$. Fishing mortality values for $C$. hippurus were higher than natural mortality values observed obtaining a total mortality of 0.9 to $5.88 /$ year $^{-1}$.

For T. lepturus, the estimated total mortality was increasing during the study period. Data for 2009 and 2011 was not provided since no modal progression was obtained. The minimum length observed for the species during the duration of the study was $15 \mathrm{~cm}$. Fishing mortality values were slightly higher than natural mortality values with an observed total mortality of 2.43 to $4.67 /$ year $^{-1}$.

The exploitation values (E) of D. macrosoma, C. hippurus, and T. lepturus obtained in this study were already beyond the sustainable level of exploitation based on the suggested sustainable exploitation rate of $D$. macrosoma, C. hippurus, and T. lepturus.
Most of the fishing boats and gears operating in Babuyan Channel is under the municipal fisheries. However, the production of commercial fisheries is higher than the municipal fisheries. This reflects higher efforts exerted by commercial fishing boats and gears in the fishing ground. Gaerlan et. al. (2002) noted that data from both commercial and municipal fisheries catches seem to increase, but more boats and more fishers do not necessarily lead to increase in production. In fact, the more effort is used the lesser catch per unit effort is observed.

Both commercial and municipal production fluctuated throughout the study period. This might be due to environmental, social, and economic factors that the fisherfolk encountered. Notably, the increasing cost of operation mainly due to the increase in fuel price, conflict with other users, and restrictions were some of the reasons that affect the production in 2010 to 2011. This was further aggravated by livelihood shifting to elvers collection in 2011 to 2012 since the price of such commodity commands higher in the local, national, and international market. However, in the earlier part of 2012 FAO 242 (reinstating the ban on the export of elvers) was approved, thus, some fishermen went back to fishing although production was still low since fishing activities were already done during lean season when the weather was unfavorable to fishing but it affected already the 2013 production. Also, the operation of commercial and municipal fishing boats and gears increased in 2013 due to favorable weather conditions.

The production was also affected by the operation of the fishing gears. Higher average CPUE was observed in Drift Filter Net and Danish Seine in the commercial fisheries. Same observation from the study of Aragon et. al. (2008) on the commercial fishing gears observed in Babuyan Channel. Meanwhile, Beach Seine followed by Scoop Net has the highest CPUE in the municipal fisheries.

In terms of catch composition, the fishing ground has diverse fish species. Most of the catches come from vertebrate species. Similar dominant species in terms of aggregate weight were observed in the study of Aragon and colleagues (2008).

$N$. tenuipes topped the production among the species caught in Babuyan Channel. It was observed that the production was mostly contributed by Drift Filter Net or locally known as "Banuar" and Pair Trawl also known as "Saplar". The gears have small mesh size making it very efficient in catching $N$. tenuipes. These gears were merely used in catching $N$. tenuipes thus, the species dominated the production. However, this species is seasonal especially when the water is turbid. The high catch of aramang was mainly attributed to the availability of market and the controlled gathering due to gentlemen's agreement formulated by the gatherers and the LGU of Aparri, Cagayan and is believed to be a strategy in the sustainability of the resource.

In the case of $A$. thazard as dominant species

\section{D I S C U S S I O N}


in the fishing ground, the peak season occurs during the months of May to July and December to January. In Japanese waters, the months of July was observed to be the peak season of this species as expressed by the index sexual maturity (FAO 2014). Meanwhile, fluctuating monthly production was observed for D. macrosoma, $G$. minuta and E. punctifer. The seasonality of these species observed in this study was the same with the seasonality observed in the study of Villarao et. al (2002) and Aragon et. al (2008).

Generally, the abundance or biological production of the top commercially important species is highly seasonal. This might be due to the influence of the environmental conditions of the area, most notably by monsoon winds and the natural close season occurring on the fishing ground. Typhoons and bad weather conditions were frequently observed after summer months and the seasonality of the species was observed to be abundant following the end of the northeast monsoon. Likewise, factors such as food availability, rainfall, sunshine duration, and salinity, wind movement and other meteorological parameters might play or affect the seasonality, distribution, and annual catch of the species.

Growth parameter estimates (i.e. $\mathrm{L}_{\max }, \mathrm{L}_{\infty}, \mathrm{K}$ value) for some commercially important species such as D. macrosoma, C. hippurus, and T. lepturus varies from 2009-2013. Growth parameters of these species obtained earlier in Babuyan Channel, as reported by Aragon et. al. (2008), were similarly close to the values obtained in this study. All the values obtained in this study are somewhat similar to the values obtained by Ingles and Pauly (1984), and Corpuz et. al. (1985). The total mortality, fishing mortality and measured lengths of these commercially important species also varied and fluctuating throughout the study period. The high value of fishing mortality obtained in these three species is an indication that fishes die more due to excessive fishing pressure than natural death. This can be related to the exploitation values of these species obtained in this study which were already beyond the optimum sustainable level of exploitation based on the suggested sustainable exploitation level of 0.05 by Gulland (1971). As observed, the exploitation rates ranging from 0.6 to 0.9 in this study is similar to the range of exploitation rates obtained by Aragon et. al. (2008) in the Babuyan Channel. The result is an indication of "growth and recruitment overfishing" caused by several factors such as reduction of the spawning stock and coastal habitat degradation, which affects the quality and size of spawning and nursery areas (Aragon et. al. 2008).

\section{C ON CLUSI ON}

Most of the fishing boats and gears operating in Babuyan Channel were under municipal fisheries sector. However, production is higher in the commercial sector suggesting that higher fishing effort was exerted by commercial fishing boats and gears in the fishing ground. The trend of annual fish production in the fishing ground is fluctuating as reflected by fluctuating production in both municipal and commercial during the study period. The fluctuating production may be due to environmental, social, and economic factors such as increasing operation cost due to increasing fuel prices, conflict, and livelihood shifting on elvers gathering in the earlier part of 2011 to 2012. The noted increase in 2013 was mainly due to strict implementation of FAO 242 banning elvers gathering and policies formulated at the local level. Drift Filter Net and Drift Gill Net dominated the commercial and municipal fisheries, respectively. There were 25 species belonging to 69 families caught in the fishing ground indicating the diversity in the area. $N$. tenuipes topped the production in Babuyan Channel caught by Drift Filter Net and Pair Trawl in the mouth of Cagayan River in Aparri, Cagayan. As observed, the fishing mortality values of commercially important species such as D. macrosoma, C. hippurus, and T. lepturus obtained was higher than natural mortality, an indication that high fishing pressure is being experienced on the fishing ground.

\section{REFER E N C E S}

Aragon MA, Ame EC, Villarao VB, Ayson JP. 2008. Status of Fisheries Resources in Babuyan Channel, Region 2, 1999-2010.

Arce FM. 1987. The Auxis spp. fisheries of Batangas, Philippines. Indo-Pac. Tuna Dev. Mgt. Programme, IPTP/87/GEN/12:137-44.

Armada NB. 2004. State of demersal fisheries. In: Department of Agriculture-Bureau of Fisheries and Aquatic Resources (DA-BFAR). In Turbulent Seas: The Status of Marine Fisheries, p. 42-46. Coastal Resource Management Project (CRMP), Cebu City, Philippines. p. 378.

BFAR-Philippine Fisheries Profile. 2013. Department of Agriculture-Bureau of Fisheries and Aquatic Resources. Elliptical Road Diliman Quezon City. p. 8.

Beverton RJH, Holt SJ. 1957. On the dynamics of exploited fish populations. Fish. Invest. Ser. II 19. p. 533

Corpuz A, Seager J, Sambilay V. Jr. 1985. Population dynamics of commercially important fishes of Philippine waters. Dept. of Marne Fisheries. Univ. of' the Philippines, Tech. Rep., 6: 1 Opp.

Gaerlan RSP, Barut NC, Buccat FGA, Bugaoan BC. 2002. An assessment of the Lingayen Gulf Fisheries, Philippines. Bureau of Fisheries and Aquatic Resources Region I; [accessed 2014 June 7]. ssme. iwlearn.org/publications/resources/referencematerials.

Gayanilo FC. Jr, Sparre P, Pauly D. 1995. FAO-ICLARM stock assessment tools (FiSAT) user's manual. FAO Comp.Info.Ser. (Fisheries) 8. p. 126. 
Gayanilo FC. Jr, Sparre P, Pauly,D. 1996. FAO-ICLARM stock assessment tools (FiSAT): User's Manual. FAO Computerized Information Series (Fisheries) No. 8. Rome, FAO p. 126.

Gayanilo, F.C. Jr., Pauly D. 1997. FAO-ICLARM stock assessment tools (FiSAT): User's Reference Manual. FAO computerized information series (Fisheries) No. 8. Rome.

Guanco MR, Mesa SV, Belga PB, Nuñal DRM. 2002. Assessment of the commercial fisheries of Western and Central Visayan Sea. p 36; [accessed 2014 June 9]. http://www.nfrdi.da.gov.ph/publications. php?page $=1$

Gulland JA. 1971. The fish resources of the oceans. FAO/ Fishing News Books, Surrey, UK.

Ingles J, Pauly D. 1984. An atlas of the growth, mortality and recruitment pattern of Philippine fishes. ICLARM Tech. Rep. 13. p. 127 International Center for Living Aquatic Resources Management, Manila, Philippines.

Pauly D, Navaluna NA. 1983. Monsoon-induced seasonality in the recruitment of Philippine fishes. FAO Fish. Rep. p. 291 (10) pp 823-833.
Pauly D. 1984. Length-converted catch curves: a powerful tool for fisheries research in the tropics (Part II). ICLARM Fishbyte 2(1): 17-19.

Pauly D, Soriano LM. 1986. Some practical extensions to Beverton and Holt's relative yield-per-recruit model. In J. L. Maclean, L. B. Dizon and L. V. Hosillo (eds), The First Asian Fisheries Forum. Asian Fisheries Society, Manila, Philippines, pp. 491-496.

Powell DG. 1979. Estimation of mortality and growth parameters from the length-frequency in the catch. Rapp. P.-v. Réun. CIEM 175: 167-169.

Villarao BV, Palolan LS, Aragon MA, Romero RO, Arizabal, AV. 2002. Catch, effort and population parameters of Coryphaena hippurus (Common Dolphinfish) and Gazza minuta (Toothpony) at Babuyan Channel. Paper presented during the 7th Commodity R n D Review for Fisheries, November 14-15, 2002, DMMSU, Bacnotan La Union.

Wetherall JA. 1986. A new method for estimating growth and mortality parameters from length-frequency data. ICLARM Fishbyte 4(1): 12-14. 